\title{
The Effect of Fatness of Cows on their Milk Production
}

\author{
Oleg K Gogaev ${ }^{1,2 *}$, Valeriy R Kairov ${ }^{1,2}$, Albina R Demurova ${ }^{1}$ and Tereza A Kadieva ${ }^{1}$ \\ ${ }^{1}$ Gorsky State Agrarian University, RNO-Alania, Vladikavkaz, Russia \\ ${ }^{2}$ North Caucasus Research Institute of Mining and Foothill Agriculture, Vladikavkaz Scientific Center of the Russian Academy of Sciences Williams \\ Street, Russia
}

Submission: January 23, 2019; Published: March 12, 2019

*Corresponding author: Oleg K Gogaev, North Caucasus Research Institute of Mining and Foothill Agriculture - a branch of the Federal State Budgetary Institution of Science of the Federal Scientific Center "Vladikavkaz Scientific Center of the Russian Academy of Sciences", Gorsky State Agrarian University, 363110, RNO-Alania, Prigorodny district, Mikhailovskoye village, Williams Street, Russia

\begin{abstract}
Cows feeding conditions and welfare should be emphasized among the numerous external factors affecting their milk productivity. High lactation performance of the cows requires the continuous presence in the blood of an animal of the substances needed for the milk production. This is provided by organization of quite abundant and continuous feeding of cows and the introduction in the animal rations of various components that allows balancing them in terms of all nutrients and bioactive substances needed by the body. Feeding cows with a complete feed should be carried out during the whole period of their economic use, because it is extremely difficult to correct the metabolic disorders caused by insufficient feeding as well as to get healthy calves in such a situation. In addition, metabolic disorders in the cow and calf due to improper diet increase the risk of developing non-communicable diseases.

The primary method of determining the physiological status of dairy cows is body condition score. To determine the fatness of cows, analysis of the dairy herd condition at "Ossetia" livestock farm located in Prigorodny district of the Republic of North Ossetia-Alania was carried out. Based on the primary zootechnical documentation, the following parameters were studied: productivity of cows of different lactations, the live weight of cows, fatness of cows, as well as the effect of fatness on milk production. Cow fatness evaluation technique developed by the All-Russian Institute of Animal Husbandry (VIZh) was used. The studies showed that the highest milk yields were observed in cows with fatness score of 3.6-4.0 points and amounted to $4584 \mathrm{~kg}$. The cows with the fatness score of 3.6-4.0 points were characterized by the longest duration of economic use. The best economic efficiency was noted in cows with the fatness score of 3.6-4.0 points.
\end{abstract}

Keywords: Diet; Fatness; Body condition score; Lactation; Duration of economic use

\section{Introduction}

Livestock production is biotechnology, which represents a system, where the main place is occupied by an animal. Without system-based implementations of zootechnical and veterinary science achievements, the proper organization of feeding and welfare, as well as application of progressive forms of labor organization, it is impossible to fulfill genetic potential inherent in the animals. The major line in the development of dairy cattle breeding is its sustainable intensification. The efficiency of this process depends on implementation of the following development patterns:

a. Full implementation and increasing the genetic potential of dairy cattle.

b. Rich and biologically complete feeding of animals.

c. Procurement in sufficient quantity of quality feed.

\section{d. Implementation of rational technologies.}

Prolonged use of cows which calve every year and retain a stable and high milk yield during many lactation periods is the key to success in dairy farming and a full supplying of food to the population. Feeding has the greatest effect on milk productivity of cows among all other environmental factors. For animal husbandry, not only the quantity but mainly the quality of the feed is important, i.e. feed value determined by nutrient content. Adequate rations and forages are those containing all substances necessary for the animal body and capable of ensuring the normal realization of all animal physiological functions for a long time $[1,2]$.

Body condition score is an in vivo method for determining the physiological status of dairy cows. The level of fat and muscle 
tissues development in animals is meant under the fatness of cows. Fatness score is determined by visual examination and handling the animal at particular reference points on the body characterized by maximum fat deposits. Such sites on the body are called handling sites. In cattle they are found in the tailhead, ischial tuberosities, pelvic area, hips, lumbar spine, ribs, and dewlap. With increasing fatness, fat accumulation in different body parts is uneven. In the first place fat is stored in the back and then in the middle and anterior parts of the animal body [3].

\section{Material and Research Methods}

Analysis of the dairy herd condition at "Ossetia" livestock farm located in Prigorodny district of the Republic of North OssetiaAlania was carried out. Based on the primary zootechnical documentation, the following parameters were studied:

\section{a. Productivity of cows of different lactations.}

b. Live weight and fatness of cows, as well as the effect of fatness of cows on milk production.

A total of 106 cows of the second lactation and older were studied. To carry out experiments at "Ossetia" livestock farm located in Prigorodny district, 4 groups of animals of the second calving and older were selected based on the principle of analogues, on average 22 heads in each group. The first group consisted of animals with the body condition score of 2.0-2.5 points; the second - 2.6-3.0; the third - 3.1-3.5, and the fourth - 3.6-4.0 points. Body condition score assessing methodology proposed by All-Russian Institute of Animal Husbandry (VIZh) [4] was used. Animals were classified by a 5-point scale (with the graduation interval of 0.5 points) where 1 point corresponded to exhaustion, while 5 points corresponded to excessive obesity. The assessed parameters of milk production included milk yield, fat, protein, quantity of milk fat and lifetime milk production of cows under study. Milk yield, mass fraction of fat and protein in milk for the testing day was recorded at the 3rd and 5th months of lactation. Body condition score of cows was determined during the same periods.

\section{Research Results}

The production of quality milk and dairy products is dependent on high genetic potential of dairy cattle, its complete feeding, contemporary technologies of animal exploitation in farms, and the advanced technologies of milk processing. The milk production of cows depends on their breed characteristics, feeding and handling conditions. It increases with increasing of milk yield; one of the main factors being the abundant feeding in winter and summer periods. Proper organization of feeding the cows is of great economic importance. Cows must be fed continuously so as to make full use of their productive capacities. The milk productivity of cows decreases with a lack of energy in the diet declining especially rapidly when it is unbalanced in protein. Milk yields reduce even more essentially with a simultaneous deficit of energy and protein in the diet. Complete feed assumes the presence of 100-110 g of digestible protein per one fodder unit of the diet [5]. In "Ossetia" livestock farm, the rations for dairy cows do not differ from diets of nonmilking cows in terms of feed composition. Per $100 \mathrm{~kg}$ of live weight, dairy cows are fed 1.5-2.5kg of fibrous feed and 4.0-5.0 kg of silage. The diet of cows includes draf in the rate of $30 \mathrm{~kg}$ per head. Concentrates are normalized depending on the level of milk production: $150-250 \mathrm{~g}$ of concentrate is used per $1 \mathrm{~kg}$ of milk.

Body condition score is an in vivo method for determining the physiological status of dairy cows. The animal fatness changes during lactation and the interlactation periods, its dynamics affects the reproductive ability of cows, the nature of the lactation activities, milk composition, metabolic diseases, and duration of economic use. Body condition score is a useful tool in determining the balance of animals' diets and modes of exploitation. Milk production depending on the quantitative assessment of the fatness of cows was studied. The research results are presented in Table 1.

Table 1: Milk productivity of Black-and-White breed cows depending on fatness.

\begin{tabular}{|c|c|c|c|}
\hline $\begin{array}{c}\text { Fatness of } \\
\text { Cows } \\
\text { (on a 5-point } \\
\text { scale) }\end{array}$ & $\begin{array}{c}\text { Average Yield } \\
\text { of Milk per } \\
\text { lactation, kg }\end{array}$ & $\begin{array}{c}\text { Duration of } \\
\text { Use } \\
\text { in Lactations }\end{array}$ & $\begin{array}{c}\text { Lifetime Milk } \\
\text { Yield, kg }\end{array}$ \\
\hline $2.0-2.5$ & $3678 \pm 83$ & $2.4 \pm 0.21$ & $8849 \pm 278$ \\
\hline $2.6-3.0$ & $3852 \pm 111$ & $3.1 \pm 0.31$ & $11981 \pm 413$ \\
\hline $3.1-3.5$ & $4108 \pm 97$ & $3.7 \pm 0.24$ & $15214 \pm 829$ \\
\hline $3.6-4.0$ & $4584 \pm 85$ & $4.1 \pm 0.28$ & $18794.4 \pm 942$ \\
\hline
\end{tabular}

It is known that in the first three months after calving the cow acutely suffers from a lack of metabolic energy, since the increase in milk yield is well ahead of the amount of consumed feed, and the cow is forced to use the internal reserves of the body for milk production. From this point of view, the more fat deposits, the higher metabolic energy reserves, the greater the body capabilities. The results of the research performed showed that the increase of body fatness of Black-and-White breed cows up to 4.0 points was accompanied by an increase in milk yields. Thus, milk production of the cows with fatness of 3.6-4.0 points was 906, 732 and $476 \mathrm{~kg}$ higher than that in animals of the other groups, $19.8 \%, 15.9 \%$ and $10.4 \%$, respectively. It should be noted that in the "Ossetia" livestock farm, no animals were identified among the cows of Black-and-White breed with fatness above 4.0 points. This suggests that cows of this breed were selected especially for intensive milk production and high milk yields per lactation. This does not allow the animal to make nutrients and metabolic energy reserves in the body at the expense of excessive fat deposits in the subcutaneous tissue and the omentum.

Besides, it should be noted that the productive longevity of the studied cows was also increased with increasing fatness of animals to 4.0 points. As it is obvious from Table 1, the lowest productive longevity was noted in the cows, whose fatness was 2.0-2.5 points and amounted to 2.4 lactation periods, while the highest productive longevity was in the cows with fatness of 3.6- 
4.0 points and amounted to 4.1 lactation periods. Accordingly, they were superior to the animals with lower fatness in terms of lifetime milk production. For the period of their use, these animals gave $18794.4 \mathrm{~kg}$ of milk that is $19-46 \%$ higher than the lifetime milk production of lower fatness cows in other groups.

\section{Conclusion}

The data obtained in the present research allow making the following conclusions:

a. The average milk productivity of the studied cows amounted to $4359 \mathrm{~kg}$ with a fat content of $3.66 \%$ at an average live weight of $476 \mathrm{~kg}$.

b. The highest milk yields were observed in the cows with the fatness of 3.6-4.0 points and amounted to $4584 \mathrm{~kg}$.

c. The highest duration of economic use was noted in cows with the fatness of 3.6-4.0 points.

Based on the foregoing, it can be concluded that milk productivity and duration of economic use depend to a large degree on fatness of animals. In view of this, the optimal feeding conditions and welfare of cows should be made to fully realize the potential of animals in terms of productivity and the extension of their economic use.

\section{References}

1. Karamaev SV, Valitov HZ, Mironov AA (2009) Vliyanie zhivoy massy korov i priploda na prodolzhitelnost ikh produktivnogo ispolzovaniya [Effect of live weight of cows and offspring on the duration of their productive use. Dairy and Beef Cattle 5: 23-24.

2. Shichkin GI (2010) Razvitie molochnogo skotovodstva v ramkakh realizatsii gosudarstvennoy programmy [Development of dairy cattle breeding in the framework of the state program] Dairy and Beef Farming 9: 13-15.

3. Karamaev SV, Valitov SV (2009) Produktivnoe dolgoletie korov v zavisimosti ot porodnoy prinadlezhnosti [Productive longevity of cows depending on the breed]. Zootechny 5: 16-19.

4. Sivkin NV, Lavelin AN, Strekozov NI (2006) Metodika otsenki upitannosti korov molochno-myasnykh porod [Body condition score assessing methodology of cows of dairy and beef breeds]. Zootechny p. 1-16.

5. Lavelin AN (2009) Upitannost korov v sukhostoynyy period i ee vliyanie na molochnuyu produktivnost i pokazateli vosproizvodstva [The fatness of cows in the nonmilking period and its effect on milk productivity and reproductive performance]. Zootechny 9: 21-23.

\section{Your next submission with Juniper Publishers will reach you the below assets}

- Quality Editorial service

- Swift Peer Review

- Reprints availability

- E-prints Service

- Manuscript Podcast for convenient understanding

- Global attainment for your research

- Manuscript accessibility in different formats ( Pdf, E-pub, Full Text, Audio)

- Unceasing customer service

Track the below URL for one-step submission https://juniperpublishers.com/online-submission.php 